logos_i_ethos_2014_1_(36), s.223-234

Szymon Szczęch

\title{
W stronę relatywizmu etycznego Ludwiga Wittgensteina
}

Artykuł Rusha Rheesa Niektóre kierunki rozwoju poglądów Wittgensteina na etykę zawiera zdecydowanie najobszerniejszą ekspozycję myśli „późnego" Wittgensteina na temat etyki - a to rzecz wyjątkowa. Chodzi przy tym

Szymon Szczęch - absolwent filozofii Uniwersytetu Jagiellońskiego. Przygotowuje pracę doktorską z filozofii Ludwiga Wittgensteina. oczywiście o prezentację, by tak rzec, „materiału źródłowego". Tekst Rheesa komentuje bowiem wprawdzie kwestie poruszane w Wykładzie o etyce - opublikowanym w tym samym numerze "The Philosophical Review” w ogóle po raz pierwszy - najbardziej cenna jest jednak ta jego część, która przedstawia zapis kilku rozmów, jakie autor odbył z Wittgensteinem w późnym okresie jego twórczości.

Ważne, by uświadomić sobie, z jak wielką rzadkością mamy tu do czynienia. Jak bowiem wraz z Traktatem logiczno-filozoficznym przestał Wittgenstein parać się filozofią w ogóle, tak napisawszy po powrocie do niej Wykład o etyce przestał wraz z nim zajmować się etyką. W Dociekaniach filozoficznych da się na jej temat znaleźć jedną tylko wzmiankę, w której występuje ona na dodatek w roli przykładu jedynie, a $O$ pewności w ogóle o niej nie wspomina. Również pozostałe pisma nie zawierają nic ponad kilka uwag rozproszonych tu i ówdzie, w których wątek etyki pozostaje zwykle w swej egzemplifikującej funkcji, nie stając się osobnym przedmiotem namysłu. Wobec takiej wybredności tych kilkanaście akapitów „żywego” Wittgensteina jawi się jako naprawdę unikalne. Wyimkowy charakter przytaczanych relacji w niczym zresztą nie umniejsza ich wagi, skoro odkrywają one to, czego chciałby się dowiedzieć każdy czytelnik Traktatu, zaintrygowany ezoteryczną niemal powściągliwością jego wypowiedzi na temat 
etyki, bądź pełnego rewerencji wobec niej Wykładu: czym etyka była dla „późnego” Wittgensteina?

Tę „stenograficzną” część artykułu Rhees rozpoczyna od wspomnienia dotyczącego zaskakującej reakcji Wittgensteina, który, zagadnięty na temat prac etycznych, odpowiada, „że jest rzeczą dziwną, iż można znaleźć książki o etyce, w których nie ma ani jednej wzmianki o prawdziwie etycznych czy moralnych problemach". Tak surowy sąd sam musiał wiązać się z jakimś osobliwym rozumieniem tego, co ów autentyczny problem moralny może stanowić. Skoro bowiem kwestię ewidentnie etyczną - propozycję Rheesa, by porozmawiać o tym, czy zabójstwo Cezara przez Brutusa było rzeczą cnotliwą, czy też wyjątkowo złą, Wittgenstein ucina krótko, mówiąc, iż nie jest to coś, o czym w ogóle można by dyskutować - a podobny los dzieli również pytanie Kierkegaarda: „Czy człowiek ma prawo dać się zabić za prawdę?” - to reakcja taka może powstać jedynie w wyniku spojrzenia na etykę całkiem odmiennego niż potocznie przyjmowane.

Powyższe i im podobne kwestie porównuje Wittgenstein do pytania o to, który z dwu patyków jest dłuższy, gdy widzi się je w powietrzu drżącym od rozgrzanego asfaltu. „Ale jeden z nich z pewnością musi być dłuższy” - może napierać rozmówca. „Jak mamy to rozumieć?” - odpowiada sceptycznie Wittgenstein. Jak mamy rozumieć odpowiedź Wittgensteina? - można by zapytać. Czy podtrzymuje on w tym miejscu pogląd z Traktatu, iż nie ma sensu zadawać takich pytań, na które z zasady nie można odpowiedzieć („Jeżeli jakieś pytanie da się w ogóle postawić, to można też na nie odpowiedzieć") $)$ ? A może mamy tu do czynienia z przekonaniem antyrealisty, iż sensowność można przypisywać tylko takim zdaniom, co do których dysponuje się świadectwami mogącymi rozstrzygnąć ich wartość logiczną?

Rhees odpowiada, że Wittgenstein chciał dyskutować tylko o takich problemach, w przypadku których można było choćby wyobrazić sobie jakieś rozwiązanie. Przekonany zaś, że propozycja Rheesa takiego nie posiada, porównuje ją do przykładu z patykami. Czy jednak te dwa pytania: o ocenę moralną zabójstwa Cezara oraz o długość patyków 
naprawdę są identyczne? Co rzekomo miałoby przeszkodzić w ocenie czynu Brutusa? Jakież to rozgrzane powietrze trzeba by rozgonić, by móc jej dokonać? W tym przypadku okoliczności takiego dociekania nie muszą wcale uniemożliwiać rozstrzygnięcia - jak ma to miejsce w przykładzie z patykami. Dlaczego Wittgenstein najprawdopodobniej nie uwzględniłby takiego zarzutu? Powróćmy do przerwanego wątku, a odpowiedź wróci za chwilę w bardziej wyrazistej postaci.

Otóż dopiero, gdy Rhees zaproponował problem człowieka, który stawia przed sobą alternatywę: albo opuścić żonę, albo przerwać badania naukowe nad rakiem, Wittgenstein zaakceptował pomysł i przeszedł do dyskusji. Rozpoczyna od tego, że postawa mężczyzny może być różna w zależności od okoliczności, po czym przedstawia ich możliwe warianty oraz ewentualne reakcje jego przyjaciela. Najciekawsza jest jednak konkluzja odpowiedzi: „Cokolwiek ostatecznie on zrobi, to jaki obrót przybiorą rzeczy w następstwie jego decyzji, może wpłynąć na jego postawę. Być może powie: «Dzięki Bogu, zostawiłem ją, ostatecznie tak jest lepiej». Albo też: «Dzięki Bogu, zostałem z nią». A może wcale nie będzie w stanie powiedzieć: «dzięki Bogu», lecz coś wręcz przeciwnego. Chcę powiedzieć, że to właśnie jest rozwiązanie problemu etycznego".

Powyższe podsumowanie zdaje się zakrawać na kpinę - nie ma tu przecież żadnego rozstrzygnięcia. Wittgenstein podaje jedynie opis tego, jakim racjom badacza można by przeciwstawić jakie racje oponenta, nie przesądza jednak, które z nich uważa za słuszne. Co więcej, podkreśla, że na ocenę powziętej decyzji wpływ będą miały także okoliczności, które nastąpią po jej podjęciu. I to wszystko miałoby być rozwiązaniem problemu etycznego?

Jak się okazuje, odpowiedź przybiera tę osobliwą postać tylko wtedy, gdy nie wiadomo, jaką etyką kieruje się stający przed wyborem. Jeśli założyć jakieś stanowisko, dylemat daje się rozstrzygnąć w sposób jednoznaczny - dlaczego? Otóż zdaniem Wittgensteina rzeczywiste rozwiązanie problemu moralnego może nastąpić tylko w ramach jakiejś etyki rozumianej jako system przekonań stanowiący podstawę czyichś wyborów. Dopiero na takim gruncie można z sensem mówić o decyzji właściwej, o słusznym postępowaniu itd. Gdy ten etyczny 
kontekst nie jest znany, wówczas nie da się orzec, jak należy postąpić, a jedyna uprawniona odpowiedź przybiera postać rozstrzygnięcia pozornego - opisu racji, jakie można wystosować za i przeciw danej decyzji. Wtedy też o jej ocenie przesądzają nie tylko same argumenty, ale również jej późniejsze konsekwencje. W większości przypadków przyjęcie pewnego systemu etycznego być może nie wyklucza wpływu, jaki na ocenę danej decyzji mają okoliczności następujące po jej podjęciu, niemniej minimalizuje go. System taki dostarcza bowiem racji, w świetle których odpowiedni wybór winien zostać dokonany niezależnie od tego, co się po nim zdarzy. Kierując się etyką chrześcijańską, przekonuje Wittgenstein, naukowiec mógłby dokonać jednoznacznego rozstrzygnięcia. Następujące po nim zdarzenia mogłyby zmienić jego życie, ale nie ocenę słuszności podjętej decyzji - chyba że stan, do którego by doprowadziła, skłoniłby go do porzucenia samej etyki chrześcijańskiej.

Etyka chrześcijańska nie jest jednak jedynym systemem moralnym, a w związku z tym decyzja badacza mogłaby być całkiem inna, gdyby był on wyznawcą np. jakiejś etyki świeckiej. Wówczas pozostanie przy żonie wcale nie musiałoby się jawić jako jedyne dozwolone wyjście z sytuacji.

Wittgenstein zgadza się oczywiście z tym, że zmiana perspektywy etycznej rzutuje na to, które rozwiązanie uważa się w danych okolicznościach za właściwe. W takiej sytuacji może ktoś jednak słusznie zapytać, która perspektywa jest odpowiednia, który system etyczny jest prawdziwy. I tutaj ujawnia się sedno poglądu Wittgensteina. Na tak postawione pytanie nie ma on innej odpowiedzi, jak tylko ta, że samo to pytanie nie ma w ogóle sensu. Pytać o to, co jest właściwe, słuszne, dobre, prawdziwe (w sensie etycznym), można tylko na gruncie jakiegoś systemu, tylko z jego wnętrza. Gdy znajdujemy się poza jakimkolwiek systemem, gdyż właśnie mamy dokonać między nimi wyboru, automatycznie stawiamy się poza możliwością poprawnego użycia powyższych wyrażeń, a więc i poza możliwością rozstrzygnięcia właściwego, słusznego, dobrego itd.

Co do takiej metadecyzji pisze Wittgenstein: „Ale nie wiemy, jak przeprowadzić takie rozstrzygnięcie - czym się kierować, jakiego rodzaju kryteriów użyć itd. Porównaj to ze stwierdzeniem, iż musi się dać rozstrzygnąć, który z dwu standardów dokładności jest właściwy. Nie 
wiemy nawet, czego poszukuje osoba zadająca to pytanie”. Gdy ktoś przyjmuje dany system etyczny, zyskuje tym samym kryteria, w świetle których może oceniać poszczególne wybory. Zrozumiałe jest więc, że sytuacja, w której należy dopiero wybrać jeden spośród takich systemów, charakteryzuje się brakiem takich kryteriów i w związku z tym uniemożliwia wybór właściwego z nich. Najważniejsze pozostaje tu słowo „właściwy”. Nie można wybrać systemu właściwego, gdyż nie ma jakiegoś metasystemu, który wybór ten by uzasadniał.

Nie oznacza to jednak, że nie można przyjąć bądź zmienić wyznawanej etyki. Oczywiście można to uczynić, ale zawsze w sposób arbitralny - bo poza jakimkolwiek systemem. Albo też z wnętrza samego tego systemu, gdy ktoś, ignorując obecne w takim rozumowaniu błędne koło, przyjmuje, że system, którego autorytet uzasadnia poszczególne decyzje moralne, uzasadnia też sam siebie. Tak czy owak, trywialny wynik takiego wyboru jest już z góry znany: kto wyznaje daną etykę, uważa ją za słuszną, inne zaś za mniej lub bardziej niesłuszne.

Zdaniem Wittgensteina nie tylko pytanie o właściwy system etyczny nie ma sensu. Równie niedorzeczne jest twierdzenie, że choć nie można wśród nich wskazać jedynie słusznego, to wszystkie są w równej mierze słuszne. A tak samo jest $\mathrm{z}$ twierdzeniem, iż każdy ma rację z własnego punktu widzenia. To ostatnie zdanie sprowadza Wittgenstein do stwierdzenia, iż każdy uważa za słuszne to, co uważa.

Teraz można już odpowiedzieć na porzucone tymczasowo pytanie, dlaczego Wittgenstein nie chciał dyskutować na temat słuszności czynu Brutusa lub kwestii postawionej przez Kierkegaarda. W obu przypadkach nie ma możliwości zbadania, co czuł i myślał człowiek, którego czyn chce się ocenić. Nieznajomość jego myśli i uczuć pociąga za sobą nieznajomość systemu przekonań moralnych, na gruncie których działał, a wedle Wittgensteina bez wyznaczenia takich ram nie sposób określić wartości jakiegokolwiek uczynku. Jedyne, co można zaproponować, to pseudorozstrzygnięcie podobne do użytego w Wittgensteinowskim przykładzie, ale również taka odpowiedź musi uwzględniać specyficzne okoliczności, w których znajduje się działający, a tutaj niczego takiego znać nie możemy. 
Z przedstawionych rozważań zdaje się wynikać dziwaczny pogląd na charakter ocen moralnych. Wittgenstein wzbrania się przed dyskutowaniem rzeczonych przykładów, zasłaniając się, jak można mniemać, nieznajomością etyki, na gruncie której ma zapaść decyzja - gdyby ją znał, mógłby wydać stosowny sąd. Ocena taka byłaby jednak czymś osobliwym - polega ona wszak na stwierdzeniu, jaka decyzja będzie słuszna w świetle takiego a takiego systemu etycznego. Sprowadzając się do badania spójności danego przekonania z resztą twierdzeń stanowiących ów system, jest sądem logicznym raczej niż etycznym. Oceny takiej równie dobrze można dokonać samemu, nie potrzeba tu wsparcia z zewnątrz, chyba że chodzi o problem szczególnie kontrowersyjny, w którym należy zasięgnąć opinii kogoś lepiej znającego meandry danej etyki. Rozstrzyganie dylematów etycznych w znakomitej i najbardziej reprezentatywnej części przypadków nie polega jednak na badaniu, czy dane rozwiązanie jest spójne z przyjętą przeze mnie etyką, lecz właśnie na wyborze samej podstawy, w oparciu o którą mam podjąć decyzję. Od kogoś, kogo proszę o radę, wymagam nie biegłości w badaniu zawartości sądów i ich konsekwencji, a mądrości i osobistego świadectwa na rzecz jakiegoś rozwiązania. Często specjalnie wybieramy kogoś, o kim z góry wiemy, że wyznaje przekonania odmienne od tych, do których przyjęcia skłania nas sytuacja, po to właśnie, by sprawdzić nasze intuicje w ogniu odmiennych racji. Dlaczego więc Wittgenstein pomija to potoczne pojęcie sądu moralnego i uchyla się od zajęcia własnego stanowiska?

Być może odpowiedź tkwi w przekonaniu, że ocen moralnych można dokonywać tylko wtedy, gdy potrafi się je uzasadnić. W przypadku, gdy nie są znane ramy etyczne danej decyzji, nie można też stwierdzić, czy jest ona słuszna, czy nie. Gdyby chcieć to uczynić, trzeba by z konieczności założyć u jej podstaw jakiś system moralny, ale wówczas wyboru jego samego uzasadnić już się nie da. W takiej mierze zaś, w jakiej nie mogę kogoś przekonać - $\mathrm{w}$ znaczeniu odwołania się do pewnych racji - do wyboru etyki, którą uważam za słuszną - gdyż jest to możliwe tylko już na gruncie jakiejś etyki - nie mogę również dokonać oceny decyzji mającej być przez osobę tę powziętą. 
Czy sądy moralne można jednak wydawać tylko wtedy, gdy mogą one zostać wyprowadzone $\mathrm{z}$ jakiegoś systemu? A może jest wręcz przeciwnie? Jeśli w oparciu o poglądy Wittgensteina oparte na racjach decyzje wewnątrzsystemowe można przeciwstawić nieuzasadnialnym decyzjom metasystemowym, to tylko te drugie noszą w moim przekonaniu znamiona rzeczywistych wyborów. W pierwszym przypadku chodzi bowiem nie tyle o wybieranie, będące działalnością woli, ile o czysto intelektualną operację wyprowadzania konsekwencji z pewnego systemu przekonań i badania koherencji danego sądu z pozostałą ich resztą. Taka quasi-decyzja to po prostu logiczny wniosek z pewnego zbioru zdań.

Oczywiście każda taka konkluzja musi zostać „zatwierdzona” przez wolę - co innego wyciągnąć wniosek logiczny, co innego zaakceptować go jako regułę własnego postępowania. Niemniej nawet ta zgoda nie potrafi w moim odczuciu obronić takiego wyboru jako prawdziwej decyzji w ogóle, w szczególności zaś jako decyzji moralnej. Autentyczne decydowanie jest bowiem ekspresją woli wewnętrznie autonomicznej, której miarą jest stopień jej wolności i odpowiedzialności, a nie zdolności do podporządkowania się logice systemu. Wola taka dokonuje wyboru przede wszystkim mocą własnej wolności i „uzasadnia” ów wybór przede wszystkim swą odpowiedzialnością zań. Decyzja będąca konkluzją systemu może spełniać te kryteria tylko czysto abstrakcyjnie. W rzeczywistości korumpuje ona oba wymienione wymiary - wolność ulega pod presją wewnątrzsystemowej racjonalności, a odpowiedzialność oddaję dostarczanym mi przezeń uzasadnieniom. I właściwie nie jestem już potrzebny.

Jeśli jednak to wolność i odpowiedzialność właśnie, nie zaś rozumowanie i podporządkowywanie się jego konsekwencjom, stanowią prawdziwą domenę etyki, to decyzję niebędącą wynikiem uprawomocniającej je dedukcji należy uznać za decyzję etyczną par excellence. Łącząc powyższe przesłanki z poglądem Wittgensteina, takim wyborem etycznym we właściwym tego słowa znaczeniu byłby wybór etyki jako podstawy wszelkich późniejszych decyzji - w przeciwieństwie do nich samych. O ile etyka czyni nas podmiotami moralnymi, o tyle jej wybór, nieuzasadnialny w sensie możliwości podania racji na jego rzecz, byłby 
przejawem tej moralnej osobowości, sposobem, w jaki manifestuje się nie-racjonalna wizja świata stanowiąca tło naszego życia.

W myśl powyższych uwag Wittgenstein nie powinien mieć jednak żadnych oporów przed zajęciem stanowiska wobec postawionych kwestii, dlaczego więc przed tym się wzbrania? Istnieje jeszcze jedna wiarygodna odpowiedź. Wittgensteinowska wizja etyki, choć na pierwszy rzut oka niekontrowersyjna, prowadzi nieuchronnie do stanowiska odczuwanego przez wielu jako problem, i to zasadniczej wagi. Otóż nieuzasadnialność wyboru określonego systemu etycznego wiedzie wprost do relatywizmu, rozumianego jako przekonanie, iż to, czy ktoś ma pewien obowiązek moralny, czy też nie, zależy od okoliczności. W przypadku poglądów Wittgensteina taką okolicznością jest wybór etyki, na gruncie której ktoś działa.

Czy Wittgensteinowska rezerwa wobec przedstawionych dylematów mogła pochodzić $\mathrm{z}$ akceptacji tych relatywistycznych konsekwencji? To niewykluczone, mimo że relatywizm postrzega się zwykle jako zagrożenie szczególne - „niszczy imperatyw w moralności”. To, że miałby go aprobować Wittgenstein, dziwi tym bardziej, iż przekonanie o jego zgubności należy przecież nie tylko do przywołanego powyżej Platona, ale również jego samego - właśnie tak dekadę przed obecnymi rozmyślaniami ujmował on istotę etyki. To nie gdzie indziej przecież jak w $W y$ kładzie o etyce traktuje wyrażenia „etyczny” i „absolutny” jako synonimy, przekonany, że zniszczenie imperatywu moralnego równoznaczne jest zniszczeniu samej etyki. Jeśli się nie mylę, przypisując mu obecnie relatywizm, to zmiana, jaka dokonała się w jego refleksji nad etyką, wyrasta na całkowite zerwanie.

Czy to jednak problem? Zdaniem Glocka trudność nowej teorii Wittgensteina przedstawia się następująco: „W jego koncepcji jest miejsce dla zobowiązania w pierwszej osobie, bowiem sądy etyczne stanowią wyraz tego, na jakich podstawach człowiek zamierza działać. Nie ma zaś miejsca dla idei powinności moralnych, wiążących wszystkich ludzi niezależnie od ich zapatrywań” ${ }^{2}$. Taka idea zaś - można dopowiedzieć za Wittgen- 
steinem z Wykładu - jest właśnie tym, co stanowi najgłębszą tożsamość etyki. Skoro nie ma uniwersalnych powinności moralnych, to nie mogę także wymagać od reprezentantów innej etyki, aby zechcieli respektować normy, które ja sam uważam za słuszne. Krytykować ich postępowanie mogę tylko w oparciu o mój własny system etyczny, a ponieważ nie mogę wykazać jego słuszności, to i sama ta krytyka pozostaje ostatecznie nieuzasadniona, choć jest konsekwencją przyjętych przeze mnie poglądów. O ile więc ktoś działa wedle zasady, iż wymagać określonych powinności od innych można tylko wtedy, gdy potrafi się je uzasadnić, o tyle też znajduje się między młotem a kowadłem: albo zachowa powyższą zasadę, odstępując jednak od uniwersalizowania wymogów własnej etyki, albo uchroni się przed relatywizmem, ale za cenę jej złamania.

Relatywizm jako rezultat Wittgensteinowskich dociekań stanowi jednak coś więcej aniżeli nieoczekiwany „wypadek przy pracy”, którego zajście trudno byłoby wytłumaczyć w świetle innych uwag autora. Warto zauważyć, że ów odmienny charakter późnych rozważań Wittgensteina nad etyką doskonale odpowiada charakterowi zmiany, jaka zaszła w całej jego twórczości - tej zmiany, która pozwala odróżniać w jego biografii intelektualnej okres wczesny i późny. Otóż odwrócenie wzroku od Etyki (zapisywanej w Wykładzie zawsze dużą literą) w stronę mnogości systemów etycznych (co ukazuje artykuł Rheesa) doskonale odpowiada innemu przejściu: od badania języka jako idealnego, logicznego korelatu świata w Traktacie logiczno-filozoficznym do rozwijanej na kartach Dociekań filozoficznych analizy gier językowych - rozmnożonych poza zasięg jakiejkolwiek jedności.

Innymi słowy, w owych późnych notatkach systemy etyczne opisuje Wittgenstein właściwie dokładnie tak samo jak gry językowe. Po pierwsze, konstytuują je pewne zasady. Po drugie, dopiero w ich obrębie pewne określone wyrażenia ( $w$ tym wypadku należące do szeroko pojętego „słownika moralnego") zyskują znaczenie. Po trzecie, znaczenia przypisywane wyrażeniom w różnych grach językowych są różne - słowa nie mają żadnego wyróżnionego, „platońskiego” sensu. Ale co najważniejsze, tak jak nie ma metazasady wyboru jakiegoś systemu etycznego, tak też nie istnieje taka metazasada co do samych gier językowych. Pytanie, 
która gra językowa jest właściwa lub prawdziwa, jest bezsensowne, skoro nie określiliśmy, na gruncie jakiej gry je zadajemy. Jedyne, co pozostaje w tym relatywistycznym gąszczu, to opisywać sposoby, na jakie gry językowe się od siebie różnią - tylko tyle i aż tyle.

Jeśli różne etyki stanowią po prostu różne gry językowe, to pytaniem pozostaje, czy wiąże je jakaś wspólna relacja, wyjaśnialna choćby w ramach teorii podobieństwa rodzinnego. Odpowiedź twierdzącą sugeruje sam Rhees: „Oczywiście różne systemy etyczne mają punkty wspólne. Muszą istnieć podstawy ku temu, by stwierdzić, że ludzie postępujący zgodnie z danym systemem wydają sądy etyczne: że uważają to lub tamto za dobre itd.. Co miałoby jednak stanowić ów wspólny mianownik rozmaitych etycznych gier językowych?

Odpowiedź na to pytanie odnaleźć można w pewnej kontrowersji, którą uchwycił Glock. Powołując się na relację Rheesa, przywołuje on pogląd Wittgensteina, wedle którego nawet przekonanie Göringa: „Słuszne jest to, co się nam podoba” można uznać za postać etyki. Jest tak dlatego - przekonuje Glock - iż Wittgenstein uważał, że z etyką mamy do czynienia tam, gdzie mowa jest o podstawach, w oparciu o które ludzie zamierzają działać ${ }^{3}$ O tyle więc miałby Wittgenstein uznawać przytoczony pogląd za rodzaj etyki, że wyraża on podstawy działania głoszącego go człowieka oraz - idąc za słowami Rheesa z wcześniejszego akapitu - iż podaje pewną wykładnię dobra. A dla Wittgensteina te właśnie cechy miałyby stanowić „rodzinny” charakter etycznych gier językowych.

Z tym poglądem Wittgensteina Glock się nie zgadza: „Do tego, by Wittgenstein utrzymał swój osąd, nie wystarczy jednak sam fakt, że slogan ten wyraża podstawy działania Göringa. Nie dlatego - jak sugerowali niektórzy wittgensteiniści - że stanowisko Göringa było nie do pomyślenia, lecz dlatego, że jest to paradygmat amoralności, nie zaś jakiejś odmiennej etyki"4. Replika Glocka kuleje jednak o tyle, o ile nie podaje postulowanej przez siebie miary, wedle której pewne poglądy stanowiłyby paradygmat moralności, a inne lokowałyby się już poza nim. Przymiotnik „etycz- 
ny” czy „moralny” może występować albo jako synonim słów: „dobry”, „właściwy”, „prawy” itd., albo też być nazwą pewnej kategorii uczynków, wyrażeń, poglądów. W przypadku odpowiedzi Glocka chodzi oczywiście o ów drugi sens. Warto zwrócić jednak uwagę, że określenie tego znaczenia, określenie, jak pojemna jest kategoria etyczności czy moralności - które sądy są moralne, a które już nie - samo nie jest wolne od oceny etycznej w pierwszym znaczeniu. A to, biorąc pod uwagę Wittgensteinowskie przesłanki, czyni z powyższego argumentu postać opisanej wcześniej nieusprawiedliwionej krytyki. Glock nie może w sposób uprawniony kategoryzować etycznych gier językowych, skoro kryteria, jakimi się posługuje, są ważne tylko na terenie jednej z nich - jego własnej. W ten sposób, wychodząc z Wittgensteinowskich przesłanek, można by odrzucić sformułowany przez niego zarzut. Ostatecznie jednak także stanowisko Wittgensteina można zaszachować jego własną bronią i zapytać, w jaką grę językową gra on sam, dostrzegający kategorię etyczności wszędzie tam, gdzie używa się słów „dobry” i „zły”? Czy i taka kwalifikacja nie jest aby zależna od jakiejś etycznej perspektywy?

Przez relatywizm jako najistotniejszą różnicę między wczesnym a późnym namysłem Wittgensteina nad etyką prześwieca jednak podobieństwo równie fundamentalne i o tyle też zdolne chyba zrównoważyć znaczenie tej zmiany. Otóż zarówno w Traktacie logiczno-filozoficznym, jak i w Wykładzie o etyce najsilniej przez Wittgensteina podkreślaną jej cechą była jej zasadnicza, nieusuwalna niewypowiadalność („Jest jasne, że etyki nie da się wypowiedzieć" $\left.{ }^{\prime}\right)$. W takiej mierze, w jakiej można uznać za nią również jej nieuzasadnialność, zaszło u Wittgensteina ciekawe zjawisko. Z wczesnego poglądu o niewyrażalności tez etycznych w Traktacie doszedł Wittgenstein do przekonania, iż są one co prawda wypowiadalne, ale tylko w ramach danego systemu etycznego. Niewyrażalność natomiast, pierwotnie przypisywana sądom etycznym, została teraz scedowana na samą etykę, rozumianą jako uzasadniający je system przekonań. Wybór tej podstawy sam nie może zostać już uzasadniony - w ścisłym tego słowa znaczeniu jest bez-podstawny. Dlatego też 
nie można nikogo do niego przekonać, argumentując za nim, a przeciw innym. Tak jak wcześniej w przypadku zasad etycznych, tak teraz w przypadku etyki jako systemu, jedyne, co pozostaje, to zobaczyć jego całokształt w świadectwie czyjegoś życia i za nim pójść.

To nowe rozumienie etyki jako podstawy wyborów moralnych zdradza również pewne podobieństwo do idei znanej z uwag o woli zawartych w Dziennikach. Wittgenstein podkreśla w nich, że etyka spełnia się źródłowo nie w poszczególnych uczynkach, lecz w sposobie patrzenia na świat - „Wola (etyczna - przyp. Sz. Sz.) jest postawą podmiotu wobec świata”'. Tę samą myśl zawiera choćby i uwaga o dobrym życiu jako świecie widzianym sub specie aeternitatis z fragmentu cytowanego przez Rheesa. Jeśli się nie mylę, dowartościowując wybór systemu etycznego jako wybór etyczny par excellence, to mamy tu do czynienia $\mathrm{z}$ ideą bardzo podobną. Czymże innym jest bowiem tak rozumiany system, jeśli nie pewnym sposobem widzenia rzeczy, świato-poglądem, który tworzą nie tylko określone pryncypia moralne, ale również cały zestaw twierdzeń na temat rzeczywistości?

Najistotniejszym podobieństwem pozostaje jednak kwestia niewypowiadalności, a w takiej mierze, $\mathrm{w}$ jakiej jest ona fundamentalna dla całości Wittgensteinowskiego myślenia o etyce, pomimo wszystkich różnic, jakie dzielą w tej materii „wczesnego” i „późnego” Wittgensteina, można mówić o niezmiennym stanowisku, które „obu” tych filozofów zawsze łączyło.

\section{Bibliografia}

1. Glock H.-J., Słownik Wittgensteinowski, tłum. M. Hernik, M. Szczubiałka, Warszawa 2001.

2. Wittgenstein L., Dzienniki 1914-1916, tłum. M. Poręba, Warszawa 1999.

3. Wittgenstein L., Tractatus logico-philosophicus, tłum. B. Wolniewicz, Warszawa 1997. 